\title{
NEW THEMES IN THE BRANCOVAN AND BULGARIAN REVIVAL ART: ROMANIAN INFLUENCES OR COMMON ORIGIN?
}

Assist. Prof. Tatyana IVANOVA,

Faculty of Orthodoxy Theology,

University "St. Kliment Ohridski", Sofia,

BULGARIA,

E-mail: tatyanaivanova@theo.uni-sofia.bg

\begin{abstract}
During the period called "Brancovan" (17th-18th century), new themes have appeared in the iconographic program of the Romanian churches. Among them are: "The Intercession of the Theotokos (the Protection of Our Most Holy Lady Theotokos and Ever-Virgin Mary)" in various representations, Eucharistic themes such as "Christvine", "Christ-precious blood", "Christ in the grave", "Christ's passions", themes of eschatological and moral-instructive character such as "The Life of the True Monk", "The Last Judgment", "The Apocalypse" etc. These have appeared in the Bulgarian lands in 18th-19th century in the art of the Bulgarian Revival. Despite the constant relationship between Bulgaria and Romania during the period of Ottoman domination the new iconographies in Bulgarian art are painted in churches where is no direct Romanian influence. This fact raises the question of the so-called indirect influences, namely the use of common models. The detailed study of the new themes proves their „Western origin”.
\end{abstract}

Keywords: New iconographies; Brancovan period; Bulgarian Revival; Western influences; prototype;

\section{INTRODUCTION}

The unification of the Romanians, whose anniversary we celebrate in 2018, made me look for the "union/unification" through Christian art, or the common phenomena in Bulgarian and Romanian art, namely the connections and mutual influences.

The subject is not new to the researchers of Christian art in Bulgaria and Romania. For the first time in 1925, Bogdan Filov laid the foundations for studying the mutual relations between Bulgarian and Romanian art ${ }^{1}$. Prof. Atanas Bozhkov later explored the interrelations between Bulgarian and Romanian art in the 14th-17th century ${ }^{2}$. Eleonora Costescu has concerned the development of the engraving, and some icons and frescoes in Romania and Bulgaria in 18th-19th ${ }^{3}$. Vera Dinova-Ruseva worked on the BulgarianRomanian relations in church art in the second half of the 19th century ${ }^{4}$. In the last decade of this century, Margarita Kuyumdzhieva has renewed the interest of the Bulgarian scientists in

\footnotetext{
${ }^{1}$ Богдан Филов, “Старо-румънско и старо-българско изкуство”, in Златорог VI, no. 4/1925, p. 191-201.

2 Атанас Божков, "Към въпроса за взаимните връзки между българското и румънското изкуство през XVI-XVII век”, in Известия на Института за изобразителни изкуства, по. 7/1964, p. 41-100.

${ }^{3}$ Eleonora Costescu, “L'art roumain et l'art bulgare aux XVIIIe et XIXe siecles”, in Revue des études sud-est européennes, VIII, no. 1/1970, p. 49-83; IDEM, "L'art roumain et l'art bulgare aux XVIIIe et XIXe siecles", in Revue des études sud-est européennes, VIII, no. 2/1971, p. 49-71.

${ }^{4}$ Вера Динова-Русева, "Българо-румънски връзки в изобразителното изкуство през втората половина на XIX век”, in Лиляна Мавродинова и др. (ed.), Традиция и нови черти в българското изкуство. София, БАН, 1976, p. 135-153.
} 
the subject ${ }^{5}$. Being engaged in research on the theme of the interrelationships and influences in the church art of Romania and Bulgaria, I have come across an interesting phenomenon. During the period called "Brancovan" (17th-18th century), new themes have appeared in the iconographic program of the Romanian churches. Among them are: "The Intercession of the Theotokos (the Protection of Our Most Holy Lady Theotokos and Ever-Virgin Mary)" in various representations, Eucharistic themes such as "Christ-vine", "Christ-precious blood", "Christ in the grave", "Christ's passions", themes of eschatological and moral-instructive character such as The Life of the True Monk ${ }^{6}$, The Last Judgment, The Apocalypse ${ }^{7}$ etc. These have appeared in the Bulgarian lands in the 18th-19th century in the art of the Bulgarian Revival.

What is the reason for the emergence of new themes during the two periods of spiritual and cultural revival/progress (the Brancovan and the Bulgarian Revival)? Is that due to a common indirect path and model or to direct influences of the Romanian art on the Bulgarian one? It is interesting, however, that the new themes are widespread in the western church painting before their appearance in Orthodox art. This raises the question of the socalled indirect influences, often "western" (Catholic) iconographic schemes and subjects, elaborated and assimilated in Russian and Ukrainian art, or in the monastic republic of Mount Athos, and circulated in Orthodox art through printed liturgical literature, prints and icon-painters' manuals. After the third quarter of the 17 th century, a powerful cultural movement began in Wallachia. Its origins lie with the leader/voivode Șerban Cantacuzino (1678-1688), and his fruitful continuation comes under Constantin Brâncoveanu (1688$1714)^{8}$. The management of the two rulers is associated with a unique cultural progress: they gather around themselves writers, translators, scholars, iconographers who have received education in Greece or Italy; many churches and monasteries are built ${ }^{9}$. Cultural renaissance in Wallachia leaves the brightest traces of secular and ecclesiastical architecture and church art. The result is a new style called "Brancovan"10. The Hurezi monastery, founded by Constantin Brâncoveanu, built and decorated from 1690 to 1703, is the zenith of Brancovan art and has become a model to follow ${ }^{11}$. In the Hurezi Monastery we find the best

\footnotetext{
5 Маргарита Куюмджиева, “Към въпроса за българо-румънските връзки през XVII век: дарителската дейност на Матей Басараб”, in Етрополската книжовна школа и българският XVII век, София, НБ “Св. св. Кирил и Методий”, 2011, p. 286-296; Idem. Влашко и българските земи през XVII век: контакти и културни взаимодействия, in Проблеми на изкуството, no. 3/2017, p. 3-13; Idem. On the Interrelations Between Wallachia and Bulgarians During the 17th Century: Benefactors and Beneficiaries, in Revue des études sud-est européennes LIV, no. 1-4/2016, p. 145-164; Idem. Some Remarks on Donations by the Wallachian Prince Matei Basarab in Bulgarian Territories, in Radu G. Păun (ed.), Histoire, mémoire et dévotion. Regards croisés sur la construction des identités dans le monde orthodoxe aux époques byzantine et post-byzantine, Seyssel, La Pomme d'or, 2016, p. 185-205.

${ }^{6}$ Corina Popa, Ioana Iancovescu, Mânăstirea Hurezi, Bucureşti, Simetria, 2009, p. 99-253; Ioana Iancovescu, "Les sources russes et ukrainiennes de la peinture au temps de Constantin Brancovan", in Revue Roumaine d'Histoire de l'Art. Série Beaux-Arts, no.14/2008, p. 101-116; Иванка Гергова, “Стилът Бранкувяну”, in Изкуство, по. 31/1996, p. 31-32.

7 Silvia Marin-Barutcieff, "Stored in the Dark' The Fall of the Angels, in Walachia's Iconography", in Transylvanian review, 21, supplement no. 1/2012, p. 201-213; Лозанова, Ралица. Пьрвообрази на Апокалипсиса в българското църковно изкуство, in Проблеми на изкуството, nо. 3, 1998, p. 40-49.

${ }^{8}$ Atanasia Văetişi, The Brancovan art. The last synthesis in Romanian art, s. a., s. 1., p. 7-33.

${ }^{9}$ Atanasia Văetişi, The Brancovan art..., p. 7-33; Иванка Гергова, “Стилът Бранкувяну”, p. 29.

${ }^{10}$ Bogdan Tataru-Cazaban, Gabriel Herea, Hurezi monastery, Segovia, Editura Artec Impresiones, 2009, p. 4856; Vasile Drăguţ, L' art de l'époque Brâncoveanu, Bucarest, Meridiane, 1971;.

${ }^{11}$ Corina Popa, Ioana Iancovescu, Mânăstirea Hurezi..., p. 23-199; Atanasia Văetişi, The Brancovan art..., p. 33-59; Bogdan Tataru-Cazaban, Gabriel Herea, Hurezi monastery, Segovia, Editura Artec Impresiones, 2009.
} 
realizations of Brancovan painting with all its characteristics. The team of icon-painters who performed the frescoes and icons in the main church of Hurezi is headed by the Greek painter Constantinos ${ }^{12}$. The painting of the main church was completed in 1694, the chapel "Nativity of the Blessed Virgin" - in 1697, the "St. Parascheva and St. Stefan" - in 1703, the "St. Apostles" - in 1698, the church "Bolnitsa" - 1699". It is considered that the iconographic programs in Hurezi were executed under the leadership of the first abbot of the monastery, $\operatorname{Ioan}^{14}$.

New for the iconography of the churches in Hurezi and the other Brancovan frescoes are themes unknown to the Romanian art until that moment. Among the new themes that appear there, as well as in nearby monasteries such as Govora and Cozya, are the iconographic themes with reference to the life and the protection of the Virgin Mary; eucharistic themes: "Christ-vine", "Christ in the grave"; didactic scenes: "The crucified monk (the life of the true monk)"; "The death of the righteous and the sinner etc. ${ }^{15}$

After the fall of Bulgaria under the Ottoman domination the population of the enslaved Bulgarian lands maintained relations with Wallachia for centuries. The direct contacts are evidenced by the care of the Wallachian rulers for Bulgarian monasteries. They give finacial support to monasteries, they are often the donors for the building of new churches and their decoration and frescoes ${ }^{16}$. The firman of Suleiman the Magnificent of 1543 is a testimonial that Radu Paisie (1535-1545) has to take care of the monks of the Rila Monastery and ensure that their rights are respected ${ }^{17}$. Other benefactors of the Rila Monastery are Alexander II Mircea (1568-1517), Micna II (1577-1583, 1585-1591), Constantin Brâncoveanu ${ }^{18}$. Matthew Basarab, Ștefan Cantacuzino pay an annual amount for the maintenance of the Holy Trinity Monastery near Turnovo ${ }^{19}$. Constantin Brâncoveanu makes donations to the Prisovski and Kapinovski monasteries near Turnovo ${ }^{20}$. In turn, the Bulgarian Metropolitans maintained close contacts with the rulers' courts in Wallachia in the 17 th and 18 th centuries ${ }^{21}$. It was also a common practice for our churches and monasteries to fraternize/bind (filiate, namely to join metochia) with Orthodox monasteries, as well is the case between many Romanian and Bulgarian spiritual centers ${ }^{22}$. Another important stratus of the Romanian society is referring to the development of Bulgarian church art. Well-to-do merchants and craftsmen from Wallachia and Transylvania had properties in Arbanassi (near Veliko Tarnovo). Their concern for the churches in Arbanassi is evidenced by the presence of Romanian icon painters and wood carvers in the village probably engaged by the Romanian donors for the work. The iconostasis of the churches "Nativity" and "St. Nikola", as well parts of the iconostasis of the church "St. George" from $18^{\text {th }}$ century were created by masters from Wallachia and are considered the earliest influence of the Brancovan style on the art of wood-carving in the Bulgarian lands ${ }^{23}$. An icon-painter from Wallachia signed in

\footnotetext{
12 Atanasia Văetişi, The Brancovan art..., p. 37; Corina Popa, Ioana Iancovescu. Mânăstirea Hurezi..., p. 147.

${ }^{13}$ Atanasia Văetişi, The Brancovan art..., p. 37-44.

${ }^{14}$ Ibidem, p. 31; Atanasia Văetişi, The Brancovan art..., p. 47, 54.

${ }_{15}^{15}$ Corina Popa, Ioana Iancovescu. Mânăstirea Hurezi..., p. 55-199.

${ }_{16}^{16}$ Маргарита Куюмджиева, “Влашко и българските земи...”, p. 4-5.

${ }^{17}$ Архимандрит Кирил Рилски, Кратки спомени из миналия ми живот 1861-1931, София, 1931, 146-147.

${ }^{18}$ Маргарита Куюмджиева, “Влашко и българските...”, р. 5.

${ }^{19}$ Маргарита Куюмджиева, “Към въпроса за...”, р. 286-296.

${ }^{20}$ Маргарита Куюмджиева, “Влашко и българските...”, р. 5.

${ }^{21}$ Ibidem, p. 5-6.

${ }^{22}$ Margarita Kuyumdjieva, “On the Interrelations...”, p. 162.

${ }^{23}$ Иванка Гергова, “Църквата “Св. Георги” в Арбанаси”, in Проблеми на изкуството, no. 3/2005, p. 47-53.
} 
the church "St. Archangels" (the middle of the 18th century): near the name of the Greek Mikhail of Thessaloniki is the sign of George of Bucharest ${ }^{24}$. So, at the end of the 17th and the beginning of 18th century, the Brancovan art has reached the Bulgarian lands in a direct path - the same icon-painters worked in Romania and Bulgaria.

In $19^{\text {th }}$ century not only the stylistic but also the iconographic changes of the Brancovan period have reached the Bulgarian lands. The problem is that the new iconographies are painted in churches where is no direct Romanian influence - no Romanian donors, relations in the church hierarchy, or Romanian icon-painters. This fact directs the study towards a common indirect model, wherethrough occur the changes in the Romanian and Bulgarian art.

The Bulgarian revival ${ }^{25}$ is a synchronous process of the Age of Enlightenment in Europe. Its historical frame is from the end of $18^{\text {th }}$ century almost to the end of 19th century $^{26}$. Starting with the new architecture style, the church art changed several decades after the writing of "Slavonic-Bulgarian History" (1762). New Bulgarian art schools were established in the second half of the 18th century (the first Bulgarian art school - Tryavna, which originated at the end of the 17 th beginning of 18 th century $)^{27}$. The new church painting had a different interpretation of the ideological, iconographic, stylistic and ornamental-decorative problems. The leitmotiv was the liberation of Bulgaria, the great Bulgarian Christian history before the Ottoman domination. There were many Slav or Bulgarian saints painted, new iconographies occurred.

The new iconographic themes in Romanian and Bulgarian painting do not accidentally come to these two periods of spiritual and cultural progress. They express the need of development, trough the medium of the iconographic program of the churches.

After the fall of the Orthodox people on the Balkans under the Ottoman domination among the independent Orthodox countries were Russia, Ukraine and Mount Atos. After the Union of Brest in 1596 between the Orthodox and the Catholic Church, Ukraine became an Orthodox mediator of western culture, and in Russia this process reached its peak in the time of Peter the Great ${ }^{28}$. In these processes, the role of Ukrainian theological thought and

\footnotetext{
${ }^{24}$ Маргарита Куюмджиева, “Влашко и българските земи...”, p. 8.

${ }^{25}$ See for example: Николай Аретов, Да мислим другото - образи, стереотипи, кризи XVIII-XX век, София, Кралица МАБ, 2001; Idem, Българското възраждане и Европа, София, Кралица МАБ, 2001; Балканският XIX век. Други прочити, София, Рива, 2006; Христо Гандев, Ранно възраждане 1700-1860, София, Култура, 1939; Idem, Фактори на Българското възраждане. 1600-1830, София, Българска книга, 1943; Румяна Дамянова, Отвъд текстовете: културни механизми на Възраждането, София, Елгатех, 2004; Кирил Топалов, Възрожденци, София, УИ “Св. Климент Охридски”, 1999; Иван Шишманов, Кирил Топалов (eds.), Избрани трудове (съставител), София, УИ “Св. Климент Охридски”, 2012. About the church art of the Bulgarian Revival see: Атанас Божков, Българска историческа живопис, София, БАН, 1980; Idem. Български приноси в европейската цивилизация, София, Булвест, 1991; Милко Бичев, Български барок, София, Наука и изкуство, 1955; Асен Василиев, Български възрожденски майстори. Живописци, резбари, строители, София, Наука и изкуство, 1965; Idem, Ктиторски портрети, София, БАН, 1960; Idem, Социални и патриотични теми в старото българско изкуство, София, Български художник, 1973; Дора Каменова, “Наивистични стенописи от Възраждането”, in Изкуство, по. 10/1979, p. 15-19; Маргарита Коева, Паметници на културата през Българското възраждане, София, Септември, 1977; Илия Конев, Българското възраждане и Просвещението, София, БАН, 1983; Иванка Гергова и др. Корпус на стенописите в България (XVIII), София, Акад. изд. Проф. Марин Дринов, 2006 etc.

${ }^{26}$ Daniela Tarabra, Saper vedere gli stili delle arti, Milano, Mondadori, 2008, p. 223-280. About the Bulgarian Revival and the Enlightenment seе Илия Конев, Българското възраждане...,

27 About the Bulgarian Revival and the Enlightenment see Daniela Tarabra, Saper vedere gli stili delle arti, Milano, Mondadori, 2008, p. 223-280; Илия Конев, Българското възраждане...,

${ }^{28}$ Елена Генова, “Модели и пътища...”, р. 52.
} 
literature, which reinterpreted in the Orthodox spirit the theological postulates of the Trident council, was determinative. The Reformed Russian and Ukrainian art have created a syncretic art of the Orthodox and Catholic worlds ${ }^{29}$. These models "satisfied" the need of new iconographies "in Orthodox spirit" and spread throughout the rest of the Orthodox enslaved lands among which Romania and Bulgaria.

The origins/models of these themes have already been studied separately in Romanian and Bulgarian art. In 2001, the Bulgarian art historian Elena Genova published a study entitled "Models and Paths of Modernization of Church Painting in Bulgarian Lands from the Second Half of the 18th and 19th Century"30. The result of her research is that she has identified the model of many of the new themes of the Bulgarian art in the western art, reached the Bulgarian lands through Russian and Ukrainian illustrated literature ${ }^{31}$. Without knowing the work of her colleague, in 2008, Ioana Iancovescu identified the prototype of a number of new themes of the Brancovan period in Russian and Ukrainian old prints and literature $^{32}$. The new iconographies are relevant to a number of thematic nuclei: 1 . The Eucharistic theme: "Christ-vine", "The Precious blood of Christ", "Christ in the grave"; 2. The Virgin Mary - "The Protection of the Mother of God", "Akatist"; 3. "Christ's passions"; 4. Themes with an eschatological or moral-instructive character - "The Last Judgment", "The Apocalypse", "The Life of the True Monk".

\section{CHRIST'S PASSIONS}

The cycle of Christ's passions began to appear in Romanian art during the Brancovan Age. This is an extremely popular subject in Ukraine, a proof of which are the many xylographic prints, and the addition of a new register on the iconostases with Christ's passions ${ }^{33}$. In Wallachia, among the most popular scenes are "Sanhedrin trial", "Pilate's court", "Flagellation", "Crown of Thorn", "Via dolorosa" and others. The themes became part of the iconographic program of the monasteries of Cozia, Provolagi, Hurezi ${ }^{34}$. According to Ioana Iancovescu some of the images resemble the icons from the church "St. Parascheva" in Lviv (first half of 17 th century) ${ }^{35}$.

The iconographic cycle with Christ's passions enters the Bulgarian painting during the National Revival ${ }^{36}$. Nikola Mavrodinov, one of the first researchers of the subject in Bulgarian art, identifies the prototype of the icon of the "Flagellation" (1819) from the church of the "Protection of the Holy Mother of God" at the Monastery in Samokov in a painting by Hans Holbein $\left(16^{\text {th }} \text { century }\right)^{37}$. The graphical model, however, served for the icon is an engraving in old-printed four-gospel from the Rila Monastery issued in Moscow in $1744^{38}$. At the center of the page is the "Resurrection of Christ" and around it are placed 12 scenes of "The Passion of Christ". A little later, in 1835 another Samokov painter Kosta

\footnotetext{
${ }^{29}$ Ibidem.

${ }^{30}$ Елена Генова, “Модели и пътища...”, p. 45-74.

${ }^{31}$ Ibidem.

${ }^{32}$ Ioana Iancovescu, "Les sources russes...".

${ }^{33}$ Ioana Iancovescu, "Les sources russes...", p. 104-105.

${ }^{34}$ Ibidem, p. 105-106.

${ }^{35}$ Ibidem, p. 105.

${ }^{36}$ Елена Генова, “Модели и пьтища...”, р. 54-56.

37 Никола Мавродинов, Връзките между българското и руското изкуство, София, Наука и изкуство, 1955, p. 57-60.

${ }^{38}$ Елена Генова, “Модели и пътища...”, р. 54; Елена Генова, Лидия Влахова, 24 утвари от Рилския манастир, София, Български художник, 1988, p. 43, note 2.
} 
Valyov used this icon as a model and painted on a canvas "The flagellation of Christ" 39 . In 1840 Zahari Zograf made some changes in the composition and painted it in the church "St. Nicholas" at the Bachkovo Monastery ${ }^{40}$. The cycle of "Passion of Christ" from the Holbein paintings and the Durer's engravings is obviously interpreted especially in the illustrated oldprinted book. That is how it became a model for many Balkan painters, for example in: an antimension of Zahari Orfelin from 1773 with 13 scenes, a collection of Peter Krastyu Zahariev with the "Resurrection of Christ" and "The Passions of the Lord" (1838) from the church in the village of Kelifarevo, a cycle of 12 drawings in a manuscript known as "Tryavna Hermeneia" in the National Historical Museum, Sofia (76-77); six frescoes "Washing of the Feet", "The Last Supper", "The betrayal of Christ", "Pilate's court", "Flagellation" and "The burial of Jesus (Entombment of Christ)" - from the chapel "John the Theologian"(1821, Rila monastery), worked by Dimitar Hristov, a copy of "The Wreath of Thorns" from the archive of Stanislav Dospevski (Inv. no. 1113) ${ }^{41}$.

\section{THE PROTECTION OF OUR MOST HOLY LADY THEOTOKOS AND EVER- VIRGIN MARY}

The Feast the Protection of the Virgin Mary is a celebration of the Blachernae miracle, where St. Andrew of Constantinople (Andrew the Fool-for-Christ or Andrew, the Fool) saw the Virgin Mary spreading her shroud over the people and protecting them with her prayer. The feast was established by the Russian Orthodox Church at the beginning of the 12 th century ${ }^{42}$. Later it was transferred to the West, where the theologians inspired the creation of new and varied iconographies in Western art. In Orthodox art, the subject has several iconographic variations, painted for the first time in Romania during the Brancovan period $^{43}$. In the narthex of the chapel $(1696-7)$ of the Hurezi monastery, the theme is depicted in its narrative version, the Virgin among saints on the clouds holds the shroud, in the form of a band resembling an orarion (stole of a deacon) over a multitude of people. In the middle of the people is St. Romanos the Melodist, Andrew the Fool for Christ points up to the Virgin Mary. Over the entrance of Hurezi refectory and in the narthex of the main church is depicted a second version of the theme of the Protection of the Virgin - the shroud of the Virgin Mary descends on herself between a group of people ${ }^{44}$. In the monastery of Govora, the iconography of the Protection of the Virgin is enriched with wings, covering a lot of people under her robe ${ }^{45}$.

At the end of 18th century "The Protection of the Virgin" became a typical subject for the Bulgarian icon-painters of Samokov art school ${ }^{46}$. The special relation to the feast and its worship in Samokov is related to the activity of the grandmother Fota (nun Theophanya) who has brought from Kyiv the veneration of the Virgin Protector and in 1772 founded the

\footnotetext{
${ }^{39}$ Елена Генова, Второ поколение..., р. 199-200.

${ }^{40}$ Елена Генова, “Модели и пьтища...”, p. 54.

${ }^{41}$ Ibidem, p. 54-56.

42 Благой Чифлянов, Православна литургика, София, Университетско издателство “Св. Климент Охридски", р. 99.

${ }^{43}$ Ioana Iancovescu, "Les sources russes...", p. 103-104.

${ }^{44}$ Popa, Corina, Ioana Iancovescu. Mânăstirea Hurezi..., p. 82, 124, 125.

${ }^{45}$ Ioana Iancovescu, "Les sources russes...", p. 104.

${ }^{46}$ Елена Генова, “Темата "Покров Богородичен” в живописта на самоковските зографи”, in Традиция, Приемственост, Новаторство. В памет на Петър Динеков, София, Акад. изд. “Проф. Марин Дринов” 2001, p. 492-508.
} 
monastery "The Protection of the Virgin" in Samokov ${ }^{47}$. All mentioned "Brancovan" iconographies are present in Bulgarian churches: the narrative one, the Virgin with the shroud and the Virgin with the wings ${ }^{48}$. Of course many of the details vary. The earliest image of the narrative version is in an icon (1819) from the Monastery of the Protection of the Virgin in Samokov, attributed as a work of Hristo Dimitrov ${ }^{49}$.

Particularly important for the distribution of the model of the Virgin with the wings is an engraving made in Pest in 1839 by order of the Rila Monastery Prior Hadji Isaiah ${ }^{50}$. At the same time was completed the fresco in the patron niche to the entrance of the church "The Protection of the Virgin" (Rila monastery) ${ }^{51}$. Mural paintings of the Virgin with wings work: Costa Valyov and his sons in the church of Elin Pelin (1863); Nikola Obrazopisov at the Dolenovo Monastery (1869); Vasil Pop Radoykov in the Sukovski Monastery, Pirot (1869), icon from the Etropole Monastery (1896), from the church of the village of Saparevo, Dupnitsa; Nikola Dospevski - icon from the church "St. Virgin Mary", Boboshevo.

Some of the rarest variations of the theme in Orthodox world are found in the Ukrainian books of homilies' engravings. They are influenced by the western iconography of Madonna Misericordia ${ }^{52}$. An Orthodox version of the Western Madonna Misericordiosa is the image of the Virgin with wings. It is a contamination of the apocalyptic "Woman in the Sun" (Revelation of St. John the Theologian, Chapter 12) ${ }^{53}$. In the Romanian and Bulgarian churches, the subject is borrowed from the Russian liturgical literature. Ioana Iancovescu mentions a more elaborate version of the theme of the Protection of Virgin Mary on the front page engraving in Paterik of Kievo-Pechorska Lavra (1678) ${ }^{54}$.

The second edition of that Paterik was translated in Romanian (1699) with the help of Archim. Ioan for the monastic brotherhood of Hurezi ${ }^{55}$. In his book "Трубы словесь проповеданныхь на нарочитые дни празниковь Господскихь и прочихь святых" (Kiev, 1674), Lazar Baranovic, Bishop Chernigovsky, published an illustration of the Virgin Mary with wings, explaining it with texts on scrolls from the feast of the Protection of the Virgin ${ }^{56}$. An image of the Virgin Mary with wings, in icons and frescoes, is also published by St. Dimitry Rostovsky in his work "Руно орошенное" (Chernigov, 1683) ${ }^{57}$.

\section{THE LIFE OF THE TRUE (RIGHTEOUS) MONK}

In the Bulgarian art, the subject is known as the Crucified Monk, but the original images have different names. In international context the scene is usually named "The life of the true monk". The scene is an allegorical representation of the meaning and purpose of monastic life. It represents the monk's temptations on the path of angel-like life. It can be summarized as follows: the life of the hermit in the wilderness is a repetition of the life of

\footnotetext{
${ }^{47}$ Елена Генова, “Модели и пътища...”, p. 62.

${ }^{48}$ Генова, Елена, Темата „Покров..., р. 492-508.

${ }^{49}$ Попова, Елена, Зографът Христо Димитров от Самоков, София, р. 130-132.

${ }^{50}$ Елена Генова, “Темата “Покров...”, p. 492-508; Елена Генова, “Модели и пьтища...”, р. 62.

${ }^{51}$ Елена Генова, “Модели и пътища...”, p. 62.

${ }^{52}$ Ibidem.

${ }^{53}$ Ibidem.

${ }^{54}$ Ioana Iancovescu, "Les sources russes...”, p. 104.

${ }^{55}$ Ibidem.

${ }^{56}$ Елена Генова, “Модели и пътища...”, p. 62.

${ }^{57}$ Ibidem.
} 
Jesus Christ from his temptations and miracles in the wilderness to his crucifixion. It is based on the Epistle of St. Apostle Paul to Galat. 6:14: “...with the cross of our Lord Jesus Christ, through whom the world is crucified, and me for the world." But, in fact, there is a complex symbolic composition that most commonly represents the Christian as a monk-recluse, resisting the worldly seduction. In the texts to the scene, both sins and virtues are often noted, and symbolic biblical and gospel quotations are selected in most of the scrolls.

Short description: "A monk is shown, crucified, with outer cassock and kamilavka, barefoot. His legs are pinned to the cross, his eyes and his mouth closed. In his hands he keeps lighted candles. On his chest there is paper in the form an epigonation. On the right side of the cross is a cave with a rounded serpent and the inscription "The Burning Hell". A young man is portrayed over the serpent's mouth, naked, blindfolded, with a bow in his hands, dropping an arrow to the monk; over the cave are depicted many snakes with bad thought's inscriptions; on the right side at the foot of the cross is depicted a spear with a gonfalon, and on the left side of the cross - tower. A man on a white horse comes out of the gates of the tower. He wears a golden vest and a coat; in his right hand he holds a glass of wine, and on his left a spear with a sponge, and near the blade a paper on which is written: "taste / try the sweetness of this world". Above him it is written: "vain world"; and beneath it is a grave from which death comes, he holds large sickle on his shoulders and clock on his head and looks at the monk. Above him the inscription: "Death and grave". Under the hands of the monk on both sides are depicted two angels. Above the cross is depicted the heavens, and on it Christ, who holds in his right hand a royal tiara, and in the left - a wreath of flowers. Under him, angels are portrayed on His two sides. Above the whole image is written: "The life of a true monk."

This description is the basis of various representations, depending on the model used and the context of the church, there are some variations: more or less explanatory texts to the scene, the personifications of sins vary - snakes, horseman, devil, bows, sometimes in front of the monk's breast is a heart, which is related to the text beside him, etc.

To conclude, the detailed consideration of the new iconographies: "Christ-Precious Blood", "Christ in the chalice", "Christ's passions", "The Protection of the Virgin", "The life of the true monk" and others has answered the question of the title: New Themes in the Brancovan and Bulgarian Revival Art: Romanian Influences or Common Origin? The new iconographies during the Brancovan period and the Bulgarian revival are not a result of interrelations between Romanians and Bulgarians but a result of the use of common models. The scenes are "western" themes, which have reached the Romanian and Bulgarian art indirectly through Russian and Ukrainian engravings and literature. This was a typical process for the Age of Enlightenment of "modernization" and "europeanisation". The syncretic form of the western models in "orthodox spirit" was extremely suitable for that purpose. Thus, although the prototypes came from the "west", the new iconographic repertoire was created entirely according to the doctrines of the Orthodox Church. 